\title{
Depreciation of Pak Rupee and Its Effects on Tax Collection by FBR
}

\author{
Farzana Munir $^{\text {a }}$, Muhammad Athar Ishaq ${ }^{\text {b }}$, Shees Khalid ${ }^{\text {c }}$, Hina Ali ${ }^{\text {d }}$ \\ ${ }^{a}$ Assistant Professor at School of Economics, Bahauddin Zakariya University, Multan, Pakistan \\ Email: farzanamunir@bzu.edu.pk \\ ${ }^{\mathrm{b}}$ PhD Scholar, School of Economics, Bahauddin Zakariya University, Multan, Pakistan \& Additional \\ Commissioner Inland Revenue / Federal Board of Revenue, Multan, Pakistan \\ Email: dratharishaq76@gmail.com \\ ${ }^{c}$ A-level Scholar, Beaconhouse College Programme, Multan, Pakistan \\ Email: sheeskhalid11@gmail.com \\ d Assistant Professor, Department of Economics, The Women University Multan, Pakistan \\ Email: hinaali@wum.edu.pk
}

\begin{tabular}{ll}
\hline ARTICLE DETAILS & ABSTRACT \\
\hline History: & This research paper is an attempt to analyze the effect of rupee \\
Accepted 05 March 2021 & depreciation on total tax col-lection and on types of tax collection. This \\
Available Online March 2021 & study employed ARDL methodology on empirical data of Pakistan for the \\
& period of 1990 to 2018 and found that depreciation of Pak rupee \\
Keywords: & negatively affects overall tax collection both in short term and long term. \\
Rupee Depreciation, Tax & Its effect is particularly detrimental in case of income tax and custom \\
Collection, Withholding Taxes, & duty. In case of income tax it deteriorates tax collection by reducing real \\
FBR, ARDL Methodology, & income of persons and businesses and in case of customs it reduces tax \\
Pakistan & collection by making imports costly. It is also found that depreciation of \\
& currency negatively effects tax collection from agriculture, industry, \\
JEL Classification: & services and imports whereas it positively effects tax collection from \\
H20, E6, C22 & consumption, CPI, remittances and interest rates.
\end{tabular}

DOI: $10.47067 /$ reads.v7i1.322

(C) 2021 The authors. Published by SPCRD Global Publishing. This is an open access article under the Creative Commons Attribution-

NonCommercial 4.0

Corresponding author’s email address: farzanamunir@bzu.edu.pk

\section{Introduction}

Since depreciation of a local currency affects the price of goods and services and consequently affects very important economic variables e.g. consumption, investment, real income, disposable income, interest rates, and government revenues; so this has been a topic of study for many researchers and most of them have studied this phenomenon in context of above mentioned variables. As proportion of cross border goods and services is increasing in the consumption mix of every economy, so impact of depreciation of local currency on prices of goods and services has increased tremendously. 


\section{Review of Economics and Development Studies, Vol. 7 (1) 2021, 63-76}

However the effect of currency depreciation on local tax collection have remained an understudied phenomenon and seldom been a focus of the researchers.

Pakistan's revenue growth is impressive but its proportion in relation to economic growth and its tax to GDP ratio is stagnant. Depreciation of Pak rupee effect has been the Achilles heel of Pakistan economy and it in turn affects many economic variables including tax collection. Depreciation of rupee affects other macroeconomic variables including imports, exports, industry, consumption, CPI, interest rate and resultantly total tax collection and tax wise collection. FBR is the premier government agency for collection of tax revenues and it collects more than $90 \%$ of the total government revenues. Since 1990, Pakistan is shifting swiftly to withholding mode of taxation which is also referred as tax deduction at source. Through withholding, the government of Pakistan is able to generate tax on transactions rather than on true income or consumption and that's why many economic indicators in Pakistan have hidden component of taxation in it.

Although tax is a fundamental economic variable but it is governed by fiscal laws which differ from country to country. Tax laws are amongst the most rapidly changing laws of any country and any study on taxation shows huge variation from country to country as it depends upon the time period of study and taxation system adopted. Each country has unique economic problems and objectives therefore it adopts different strategies to fulfill its economic requirements. Majority of the studies done only refer to the figures of tax collection and use dummy variables for referring socio-economic conditions like transparency, corruption, compliance to tax laws etc. These studies are normally done by the economists who are not very well aware of change in the tax laws and tax administration. Change in tax laws is a very important factor which affects tax collection.

The studies done earlier in Pakistan regarding taxation were limited to total tax collection which was usually taken as a dependent variable and determinants of tax collection were taken as independent variables. These studies were lacking various aspects as they did not studied effects of variables on types of taxes i.e. direct taxes or indirect taxes. The studies also did not properly identified effects of withholding mode of collection on various variables. For example, rural sector is usually not studied in the tax research based on the assumption that agriculture income is not under tax net. However due to withholding mode of taxation the FBR is able to tax its consumption in income tax and sales tax. The studies done earlier looked at tax collection in terms of nominal values only and tax collection in real terms was not studied. This research has also studied the changes in constitution and tax laws which could result in abnormal behavior of the variables. The studies done earlier have looked at agricultural sector behavior in total tax collection. This study has studied impact of agriculture sector in total tax collection through impact of consumption of taxable supplies and tax collection through withholding mode of collection. This research tries to fulfill the shortcomings of previous research and find out the relationship between depreciation of Pak Rupee and its effect on total tax collection by the FBR as well as on different types of taxes collected by FBR. This research has also studied the set of variables which affect particular types of taxation.

This study has tried to answer the following questions in case of Pakistan for the period of 1990 to 2018.

- How depreciation of Pak rupee affects total tax collection in aggregate?

- How depreciation of Pak rupee affects tax collection by categories /types of taxes?

- To find out the possible variables that affect total tax collection and its categories, specifically in Pakistan. 


\section{Review of Economics and Development Studies, Vol. 7 (1) 2021, 63-76}

Different categories of literature are available that discuss the effect of depreciation of local currency on tax collection. These categories are made on the basis of the researcher's findings as discussed below:

Sargent \& Wallace (1973), Frenkel (1977) and Jacobs (1977) in their research found that there is a no correlation between inflation and tax collection. Olivera (1967), Dutton (1971) and Aghevli \& Khan (1978) in their studies based on the fiscal deficit and inflation, found no relationship between depreciation and tax collection. Ghura (1998) in his study on developing countries, Patinkin (2001) in his study on France, Khattry \& Mohan (2002) in their study on 80 countries and Ayodele \& Obafemi (2003) in their study on Nigeria could not find any relationship between currency depreciation and tax collection specially in case of international trade taxes .

Bird, R.M.(1976) and Krueger (1978) in his study on Turkey, Gulhati (1986) in her study on Israel, Ebrill (1999) in his study on 105 developing countries and Tayyaba (2012) in her study found that there is a positive relation between currency depreciation and tax collection through the channel of inflation. They found that depreciation promotes inflation and higher inflation in effect increases tax collection.

Costantino (1948) in his study on Germany after I and II World War, found that that in case of hyperinflation the real government revenue decreases. Bird, R.M. (1976) observed that currency devaluation can affect tax collection on both sides (increase or decrease).The behavior depends upon the impact of tax on supply chain and value chain and velocity of circulation of money. Aghevli and Khan (1978), Gulhati et al. (1986) studied this phenomenon in India, Roca and Priale (1987) in their study on Peru, Hossain (1987) in his study on Bangladesh found similar results. Liam P. Ebrill and Janet Gale Stotsky (1999) found that deprecation of local currency leads to decrease in taxes on trade. Turley (2005) and Baunsgaard and Keen (2005) studied this phenomenon in a cluster of developing countries and found similar relationship. Tanzi, Vito (2007) studied this phenomenon in case of Argentina and observed consistent results.

Roca and Priale (1987) studied this phenomenon in context of Structural Adjustment Programme for Peru, Zambia and Ghana and found that depreciation effects tax collection in either way but it depends upon the economic system of the country. IMF in its Government Finance Statistics Yearbook (1989) observed that developed countries rely more on the trade taxes whereas the developing countries rely more on the income tax and sales tax and as a result currency value of most developed countries is not volatile and therefore the effect of currency depreciation on revenue in developed countries is not significant whereas it is significant in case of developing countries. Craig S. Hakkio (1991) observed that evidence on relationship between budget deficits and the exchange rate varies from countries to countries and it in turn depends upon the economic and taxation system adopted by the country. Adam, Bevan, and Chambas (2001) examined the relationship between tax revenue, exchange rate, and trade openness in Sub-Saharan Africa using a difference generalized Method of Moments (GMM) dynamic panel estimation and their results varied from country to country. Eichengreen and Choudhry (2005) in their study found that the relationship depends upon the taxation system adopted by a country. Teresa Ter-Minassian (2007) in IMF papers found that depreciation effects tax collection but it depends upon the exchange rate system of that country.

Bilquees (2004) in her study on Pakistan found that GDP growth has positive and significant relationship with Sales Tax collection in Pakistan. Chaudhry and Munir (2010) in their study on Pakistan took data of 37 years and found that manufacturing sector, external debt, tax base, foreign 


\section{Review of Economics and Development Studies, Vol. 7 (1) 2021, 63-76}

remittances and openness of economy has positive whereas service sector, agriculture sector, devaluation, foreign aid and low literacy rate have negative relationship with tax collection.

The paper is further divided into different parts. Part 2 deals with conceptual framework, Part 3 is related to data and estimation methodology. Part 4 deals the effect of different variables on total taxes and types of taxes. The last part is related to conclusion and policy recommendations.

\section{Conceptual Framework}

Effects of currency depreciation on tax collection depends on a number of factors including extent and coverage of tariff and taxes, price elasticity of demand, income elasticity of demand, rate of tariff, velocity and circulation of money, inventory level, balance of payments, trade regulations, local value addition, business response to change in tax laws and depreciation, substitute development and effect on real and disposable income.

\subsection{Effects of Currency Depreciation on Tax Collected at Import and Export Stage}

With currency depreciation the price of imported goods increases and thus the revenue from import duties may either decreases or increase depending on price elasticity of demand. However depreciation of local currency also boosts up exports and custom duties on exports increases. The net effect depends upon the structure of the imports and exports, their elasticities and tax system of the country. Increase in prices of imported goods increases profit margin of the persons engaged as importers but it happens only in the short term. Increase in prices of imported goods is a good incentive to local production of indigenous products and the government revenue may increase in terms of local taxes. On the contrary reductions in tariff leads to lower prices for imported goods and services, which lead to increase in profit/margins and thus higher collection of taxes on income and profits.

\subsection{Effects of currency depreciation on income (tax), profits and capital gains}

Throughout the world, taxes on income and profit are collected directly at the end of financial year or it is collected on periodic basis on the principle of withholding tax regime. As per doctrines of classical economics, depreciation of the local currency does not have any effect on profit and income of business and individual in the long runs as all the variables are adjustable in the long run. However in the short run, increase in price negatively affects income and profits of business and thus tax collection decreases. The profitability is also dependent upon the inventory levels, and their management style.

Depreciation results in inflation and inflation can enhance tax burden under the income tax laws on individuals. The income tax laws are usually designed on the canon of ability to pay principle and there are higher tax rates for persons in the higher tax income bracket. In case if the nominal income increases then it is affected by the higher tax bracket and this phenomenon is known as "Bracket Creep". If the government does not allow revision of income tax brackets then the tax revenues increases and in cases when government allow them to vary with advent of inflation then the revenue falls. Currency devaluation also decreases nominal value of tax exemptions, credits and deductible allowances. In case if they are allowed as a percentage of profit then the amount of tax may increase or decrease but in case if they are given in fixed currency terms then its effects on the revenue is positive. However, if inflation results in decline in the personal income then the effect of devaluation on tax revenue collection is always negative.

Devaluation usually results in an increase in interest rates because inflation risk premium is charged at time of calculation of interest, as a result of it income of those person receiving interest increase and income of persons who are paying interest decreases and thus the government revenues are affected proportionately. Those businesses who have borrowed capital on interest observes a 
Review of Economics and Development Studies, Vol. 7 (1) 2021, 63-76

decrease in their income in the short run but in long run the effect gets subside. As in tax laws of most of countries the interest expense is allowed as a deductible allowance from the gross profit therefore the net profit decreases and the income tax decreases.

\subsection{Effects of Currency Depreciation on Sales Tax/VAT}

The effect on sales tax and value added tax depends upon the method of taxation and firm's management decisions. In case of fast-moving consumer goods and where the tax is collected on the basis of sales, the devaluation results in the higher revenue. However, this phenomenon is also largely dependent upon the price elasticity of demand and in case of goods having high price elasticity the revenue declines. The effect of devaluation also depends upon the firm's decisions. In some cases, the firms decide not to transfer the hike in price to the consumers for taking market share and in such scenario revenue collection remains unaffected. But this phenomenon is temporary and in the long run this decision is not feasible.

\section{Data and Methodology}

In the light of literature review and on basis of tax collection relationship, following variable were selected for our study that are shown in table 1. Their expected signs and sources of data are also mentioned in this table.

Table1: Variable, their Expected Signs and Source of Data

\begin{tabular}{|l|l|l|l|}
\hline Variable & $\begin{array}{l}\text { Abbreviation } \\
\text { used }\end{array}$ & Data Source & $\begin{array}{l}\text { Expected } \\
\text { Sign } \\
\text { (+ve or -ve) }\end{array}$ \\
\hline $\begin{array}{l}\text { Total Tax (Dependent } \\
\text { Variable) }\end{array}$ & (taxt) & FBR Year Books & \\
\hline Exchange Rate & (dollar) & State Bank of Pakistan Reports & + \\
\hline Consumption & (consum) & Economic Survey of Pakistan & + \\
\hline Imports & (import) & Economic Survey of Pakistan & + \\
\hline Interest Rates & (ir) & State Bank of Pakistan Reports & - \\
\hline Agriculture output & (agr) & Economic Survey of Pakistan & + \\
\hline Services out put & (serv) & Economic Survey of Pakistan & + \\
\hline Rural Population & (ruralp) & World Bank Development Index & + \\
\hline Industrial output & (ind) & Economic Survey of Pakistan & + \\
\hline Consumer Price index & (cpi) & World Bank Development Index & + \\
\hline (remit) & Economic Survey of Pakistan & + \\
\hline
\end{tabular}


Review of Economics and Development Studies, Vol. 7 (1) 2021, 63-76

Descriptive analysis of the data is analyzed, and the results are reported as under:

Table: Basic statistics for the whole sample, 1990-2018

\begin{tabular}{|c|c|c|c|c|c|c|c|c|}
\hline & Mean & Median & Maximum & $\begin{array}{l}\text { Minimu } \\
\text { m }\end{array}$ & $\begin{array}{l}\text { Std. } \\
\text { Dev. }\end{array}$ & $\begin{array}{l}\text { Skewnes } \\
\text { S }\end{array}$ & Kurtosis & $\begin{array}{l}\text { Observation } \\
\mathrm{s}\end{array}$ \\
\hline Agr & $\begin{array}{l}2494 \cdot 77 \\
\text { o }\end{array}$ & 1164.751 & 7764.218 & 197.400 & $\begin{array}{l}2481.38 \\
2\end{array}$ & 0.903 & 2.322 & 29 \\
\hline Consum & $\begin{array}{l}9755 \cdot 78 \\
5\end{array}$ & 4647.179 & $\begin{array}{l}32499 \cdot 75 \\
\text { o }\end{array}$ & 760.912 & $\begin{array}{l}9915.06 \\
8\end{array}$ & 0.967 & 2.561 & 29 \\
\hline Cpi & 8.368 & 7.921 & 20.286 & 2.529 & 4.163 & 0.637 & $3 \cdot 418$ & 29 \\
\hline Dollar & 63.700 & 60.022 & 109.857 & 21.707 & 27.914 & 0.126 & 1.788 & 29 \\
\hline Import & $\begin{array}{l}17731.57 \\
\text { o }\end{array}$ & $\begin{array}{l}4749 \cdot 95 \\
5\end{array}$ & $\begin{array}{l}73457 \cdot 52 \\
\text { o }\end{array}$ & 434.244 & $\begin{array}{l}21236.17 \\
0\end{array}$ & 1.116 & 3.019 & 29 \\
\hline Ind & $\begin{array}{l}2145.87 \\
\text { o }\end{array}$ & 1416.986 & 6251.345 & 191.400 & 1971.837 & 0.789 & 2.148 & 29 \\
\hline Remit & $\begin{array}{l}58462.2 \\
40\end{array}$ & $\begin{array}{l}13514.99 \\
0\end{array}$ & $\begin{array}{l}253706.0 \\
\text { oo }\end{array}$ & $877 \cdot 304$ & $\begin{array}{l}80548.2 \\
80\end{array}$ & 1.245 & 3.060 & 29 \\
\hline Ruralp & 103.921 & 103.742 & 134.404 & 74.733 & 18.225 & 0.032 & 1.794 & 29 \\
\hline Serv & 5565.162 & $\begin{array}{l}2668.79 \\
\text { o }\end{array}$ & 18391.390 & 371.051 & $\begin{array}{l}5652.47 \\
0\end{array}$ & 0.949 & 2.541 & 29 \\
\hline
\end{tabular}

Source: Authors' calculations based on data.

Majority of data is spread within spread of two standard deviations, so the data is acceptable up to confidence of $66 \%$. On checking for skewness most of variables are in acceptable range from -1 to +1. Credit, remittances and imports are exceptions which are highly skewed and the reasons for them are explainable. The credit with skewness of 1.200 is skewed because after 9/11 terrorist attacks in United States a large amount of money was transferred to Pakistan by Pakistanis living abroad and this caused real interest rate to be negative and commercial banks reserves increased to the extent of bubble. Same applied to the remittances with skewness of 1.245. Skewness in imports valuing at 1.116 is related to the government policies which witnessed a high bill of imports during 2009 to 2013 due to increase in bill of oil due to skyrocketing prices of oil and they again witnessed an increase after 2015 due to import of industrial machinery for installation of power plants and development of CPEC projects. For kurtosis the variables are in acceptable range, with exceptions of credit having kurtosis of 3.285, remittance having kurtosis value of 3.060 and imports having kurtosis value of 3.019. These variables also have skewness and are also in normal range, and reasons are the same as discussed above. 


\subsection{Estimation Methodology}

After checking the variables for stationarity (results are not shown due to length of the article), this study uses Auto regressive distributive lag (ARDL) technique. FMOLS and ECM techniques with Hannan Quinin criteria are used for cross checking of results. The values are taken at 1st difference with trend and intercept level, with one lag for dependent variable and no lag for independent variables. One lag for dependent variable is used because the independent variable are determined on the basis of fiscal policy which are announced at time of budget and it takes time to get momentum and produce result. So, taking one lag for dependent variable will adjust the difference of time lag involved.

\section{Results and Discussion}

\subsection{Determinants of Total Taxation}

The regression equation \& econometric form including all variables is as under

Tax $_{t}=\alpha+\beta_{1}$ dollar $_{t}+\beta_{2} \operatorname{serv}_{t}+\beta_{3}$ ind $_{t}+\beta_{4}$ agr $_{t}+\beta_{5}$ consum $_{t}+\beta_{6}$ ir $_{t}+\beta_{7}$ cpi $_{t}+\beta_{8}$ remit $_{t}+\beta_{9}$ import $_{t}+$ $\beta_{10}$ ruralp

Table 3: Comparative results of model specification on ARDL, FMOLS and ECM

\begin{tabular}{|c|c|c|c|}
\hline & ADRL & FMOLS & ECM \\
\hline \multirow{3}{*}{$\mathrm{C}$} & -825.650 & -478.927 & -783.897 \\
\hline & $(426.561)$ & $(249.998)$ & $(-525.835)$ \\
\hline & {$[-1.936]^{*}$} & {$[249.998]^{*}$} & {$[-1.491]$} \\
\hline \multirow{3}{*}{$\mathrm{d}($ dollar $)$} & -10.201 & -6.639 & -8.445 \\
\hline & $(5.084)$ & (2.939) & -6.310 \\
\hline & {$[-2.007]^{*}$} & {$[-2.259]$} & {$[-1.338]^{*}$} \\
\hline \multirow{3}{*}{$d($ serv $)$} & -0.253 & -0.091 & -0.168 \\
\hline & (o.191) & $(0.106)$ & $(-0.239)$ \\
\hline & {$[-1.323]$} & [-0.859] & {$[-0.705]$} \\
\hline \multirow{3}{*}{ d(ind) } & -0.171 & -0.183 & -0.088 \\
\hline & $(0.172)$ & (0.101) & $(-0.224)$ \\
\hline & {$[-0.991]$} & {$[-1.802]^{*}$} & {$[-0.391]$} \\
\hline \multirow{3}{*}{ d(agr) } & -0.337 & -0.483 & -0.332 \\
\hline & $(0.148)$ & (o.079) & $(-0.156)$ \\
\hline & {$[-2.277]^{* *}$} & {$[-6.131]^{* * *}$} & {$[-2.124]^{*}$} \\
\hline \multirow{3}{*}{$\mathrm{d}($ consum $)$} & 0.250 & 0.272 & 0.203 \\
\hline & $(0.120)$ & $(0.070)$ & $(-0.145)$ \\
\hline & {$[2.078]^{*}$} & {$[3.868]^{* * *}$} & {$[1.403]^{*}$} \\
\hline
\end{tabular}


Review of Economics and Development Studies, Vol. 7 (1) 2021, 63-76

\begin{tabular}{|c|c|c|c|}
\hline \multirow{3}{*}{$\mathrm{d}(\mathrm{ir})$} & 20.244 & 9.928 & 18.344 \\
\hline & $(10.288)$ & $(5 \cdot 735)$ & $(-11.175)$ \\
\hline & {$[1.968]^{*}$} & {$[1.731]^{*}$} & {$[1.642]$} \\
\hline \multirow{3}{*}{$d($ cpi) } & 6.858 & 5.785 & 7.275 \\
\hline & $(5.114)$ & (3.010) & $(-5 \cdot 596)$ \\
\hline & [1.341] & {$[1.922]^{*}$} & {$[1.300]$} \\
\hline \multirow[t]{3}{*}{$\mathrm{d}($ remit $)$} & 0.010 & 0.007 & 0.008 \\
\hline & $(0.002)$ & (0.001) & $(-0.004)$ \\
\hline & {$[4.271]^{* * *}$} & {$[5.993]^{* * *}$} & {$[2.073]^{* * *}$} \\
\hline \multirow{3}{*}{ d(import) } & -0.018 & -0.015 & -0.022 \\
\hline & $(0.008)$ & $(0.005)$ & $(-0.010)$ \\
\hline & {$[-2.227]^{* *}$} & {$[-3.264]^{* * *}$} & {$[-2.058]^{* *}$} \\
\hline \multirow{3}{*}{ d(ruralp) } & 427.641 & $249 \cdot 337$ & $399 \cdot 409$ \\
\hline & $(211.367)$ & $(123.729)$ & $(-261.856)$ \\
\hline & {$[2.023]^{*}$} & {$[2.015]^{*}$} & {$[1.525]^{*}$} \\
\hline R-squared & 0.875 & 0.838 & 0.877 \\
\hline Adjusted R-squared & 0.784 & 0.736 & 0.764 \\
\hline S.E. of regression & 67.648 & $74 \cdot 735$ & 71.284 \\
\hline Mean dependent variable & 138.130 & 138.130 & 142.316 \\
\hline S.D. dependent variable & 145.478 & $145 \cdot 478$ & 146.691 \\
\hline Log likelihood & -144.163 & & -138.815 \\
\hline F-statistic & $9 \cdot 568$ & & 7.739 \\
\hline
\end{tabular}

Note : Standard Errors are shown in parenthesis ( ) while t- statistics are shown in brackets [ ], where* shows the probability at $10 \%$ i.e. $<0.1{ }^{* *}$ shows the probability at $5 \%$ i.e. $<0.05$ and ${ }^{* *}$ shows the probability at $1 \%$ i.e. $<0$.01

The results are nearly the same as given in the literature findings except the differences due to behavior of industrial and service sector. $\mathrm{R}^{2}$ by ARDL methodology is 0.8753 which means that this model explains $87.5 \%$ of variation in tax collection is explained by the set of explanatory variables taken.

The results show that the dollar which represents depreciation and devaluation of rupee has negative effect on tax revenue. This relationship is also statistically significant at $5 \%$ level of 


\section{Review of Economics and Development Studies, Vol. 7 (1) 2021, 63-76}

significance. These findings are in accordance with theoretical framework and findings of Chaudhry \& Munir (2010).

Similarly, service, industry, agriculture and import have negative correlation with the tax revenue. The agriculture usually has a negative correlation with tax growth as pointed out by Wolde Mariam (1997) Ghura (1998), Leothold (1991), and Gupta (2007) and by Chaudhry \& Munir, (2010). It is obvious in case of Pakistan because the income tax collection on agriculture is a provincial subject as per constitution, and is collected by the provincial land revenue authorities and its collection is minimal i.e. about Rs. 2 billion per year for whole of Pakistan and is not reported in the tax collection by the FBR. The FMOLS also verifies it with coefficient value of -0.4825 .

The services sector has a positive impact on tax collection as pointed out by Bahl (2003), Alm et al(2004) Bilqees (2004), Ahmad and Mohammad (2010). However in this study a negative relationship is noted. On ARDL the coefficient value is -0.2531 , it is -0.914 on FMOLS and -1.1681 on ECM and is insignificant. Chaudhry \& Munir (2010) in their study also found a negative correlation between tax collection and service growth and they attributed it to the growth of informal and untaxed sub-sectors in service sector.

However, consumption, interest rate, CPI, remittances and rural population have positive correlation with tax revenue. Since consumption is subject to tax at each stage of economic activity, the tax on consumption is first charged at import stage and then collected by other type of taxes i.e. Customs, Sales Tax, Income Tax and Federal Excise. Positive interest rate impact is due the fact that interest payments are subject to the deduction of withholding tax under section 151 of Income Tax Ordinance, 2001, and an increase in interest rates also increase the tax collection. Positive association of $\mathrm{CPI}$ is in consonance with literature review because consumptions is subject to income tax, sales tax, customs and federal excise at various stages as discussed earlier. Moreover, due to extractive power of withholding taxes it can even tax previous and past savings which is brought into economy by consumers during period of inflation just to meet the necessary expenses. Moreover, higher CPI increases velocity and circulation of money which is taxed at time of every transaction. Although the remittances are exempt from income tax and have no direct relationship with the tax collection. Their relationship is due to the facts that remittances are half of Pakistan's total foreign exchange earnings and helps in maintaining the value of rupee stable. They are the source of living for a substantial part of both rural and urban population and due to consumption generated from the remittances, tax is collected indirectly through consumption. Since the living standards of rural areas is converging towards the urban style and through the process of withholding the government is receiving the tax from the rural population as well. The government is also receiving the tax through the electricity and mobile phone services as well.

Imports have a negative relation with the tax revenue with coefficient of -0.0179 using ARDL and -0.0154 through FMOLS which is highly significant at 5\% level. As discussed, depreciation of local currency makes import costly and their purchases decline consequently the tax on the imports decline.

\subsection{Type wise determinants of taxation}

In order to find out that how the above considered variables effect different types of taxes the study is repeated on different types of taxes and ARDL model was used. The mathematical models are as under: 
1. Income Tax $=\alpha+\beta_{1}$ dollar $+\beta_{2}$ agr $+\beta_{3}$ serv $+\beta_{4}$ import $+\beta_{5}$ remit $+\beta_{6}$ consum

2. Sales Tax $=\alpha+\beta_{1}$ dollar $+\beta_{2}$ agr $+\beta_{3}$ import $+\beta_{4}$ remit $+\beta_{5}$ consum $+\beta_{6}$ cred

3. Customs $=\alpha+\beta_{1}$ dollar $+\beta_{2}$ import $+\beta_{3}$ ind $+\beta_{4}$ serv $+\beta_{5}$ consum $+\beta_{6}$ cred $+\beta_{7}$ ir

4. $\quad$ Federal Excise $=\alpha+\beta_{1}$ dollar $+\beta_{2}$ agr $+\beta_{3}$ ind $+\beta_{4}$ serv $+\beta_{5}$ import $+\beta_{6}$ remit + $\beta_{7}$ cred $+\beta_{8}$ ir

Econometric results are tabulated as under:

Table 4: Effect of variables on different types of taxes

\begin{tabular}{|c|c|c|c|c|}
\hline & Income Tax & Sales Tax & Customs & Federal Excise \\
\hline \multirow[t]{3}{*}{ d(dollar) } & -1.800 & 1.388 & -0.203 & 0.255 \\
\hline & $(1.713)$ & $(1.650)$ & $(0.795)$ & $(0.388)$ \\
\hline & {$[-1.051]$} & {$[0.841]$} & {$[-1.872]^{*}$} & [0.659] \\
\hline \multirow[t]{3}{*}{$d(a g r)$} & -0.209 & -0.221 & & 0.039 \\
\hline & $(0.055)$ & $(0.056)$ & & $(0.014)$ \\
\hline & {$[-3.831]^{* * *}$} & {$[-3.936] * * *$} & & {$[2.842]^{* * *}$} \\
\hline \multirow[t]{3}{*}{ d(import) } & -0.008 & -0.017 & -0.002 & -0.002 \\
\hline & (0.003) & $(0.004)$ & $(0.002)$ & (0.001) \\
\hline & {$[-2.287]^{* *}$} & {$[-4.736]^{* * *}$} & {$[-1.366]$} & {$[-2.857]^{* * *}$} \\
\hline \multirow[t]{3}{*}{ d(remit) } & 0.002 & 0.003 & & 0.0004 \\
\hline & $(0.001)$ & $(0.001)$ & & $(0.0002)$ \\
\hline & {$[3.021]^{* * *}$} & {$[3.278]^{* * * *}$} & & {$[2.120]^{* *}$} \\
\hline \multirow[b]{3}{*}{$\mathrm{d}($ serv $)$} & -0.062 & & -0.139 & -0.018 \\
\hline & $(0.055)$ & & (0.041) & (o.oog) \\
\hline & {$[-1.137]$} & & {$[-3 \cdot 384] * * * *$} & {$[-2.043]^{*}$} \\
\hline \multirow[b]{3}{*}{$\mathrm{d}($ consum $)$} & 0.116 & 0.109 & 0.084 & \\
\hline & $(0.036)$ & $(0.024)$ & $(0.027)$ & \\
\hline & {$[3.206]^{* * *}$} & {$[4.539]^{* * *}$} & {$[3.128]^{* * *}$} & \\
\hline \multirow[b]{2}{*}{$\mathrm{d}(\mathrm{cred})$} & & 0.043 & 0.065 & 0.012 \\
\hline & & (0.019) & $(0.011)$ & $(0.004)$ \\
\hline
\end{tabular}


Review of Economics and Development Studies, Vol. 7 (1) 2021, 63-76

\begin{tabular}{|c|c|c|c|c|}
\hline & & {$[2.346]^{* *}$} & {$[6.025]^{* * *}$} & {$[2.853]^{* *}$} \\
\hline \multirow[b]{3}{*}{$\mathrm{d}(\mathrm{ir})$} & & & 1.900 & 1.465 \\
\hline & & & $(1.506)$ & $(0.723)$ \\
\hline & & & {$[1.260]$} & {$[2.028]^{*}$} \\
\hline \multirow[b]{3}{*}{ d(ind) } & & & -0.120 & -0.019 \\
\hline & & & (0.039) & $(0.012)$ \\
\hline & & & {$[-3.077]$} & {$[-1.656]$} \\
\hline Variable & Coefficient & Std. Error & t-Statistic & Prob. * \\
\hline $\mathrm{D}(\operatorname{INCOMT}(-1))$ & 0.381 & 0.177 & 2.157 & 0.044 \\
\hline $\mathrm{C}$ & 7.609 & 10.857 & 0.701 & 0.492 \\
\hline R-squared & 0.832 & $\begin{array}{l}\text { Adjusted } \quad \text { R- } \\
\text { squared }\end{array}$ & 0.770 & \\
\hline $\mathrm{D}(\mathrm{ST}(-1))$ & -0.489 & 0.152 & -3.211 & 0.005 \\
\hline $\mathrm{C}$ & -1.656 & 10.339 & -0.160 & 0.874 \\
\hline R-squared & 0.859 & $\begin{array}{l}\text { Adjusted } \quad \text { R- } \\
\text { squared }\end{array}$ & 0.807 & \\
\hline D(CUSTOMS(-1)) & -0.203 & 0.229 & -0.889 & 0.386 \\
\hline $\mathrm{C}$ & 8.133 & 5.282 & 1.540 & 0.141 \\
\hline R-squared & 0.890 & $\begin{array}{l}\text { Adjusted } \quad \text { R- } \\
\text { squared }\end{array}$ & 0.842 & \\
\hline $\mathrm{D}(\mathrm{FED}(-1))$ & 0.472 & 0.159 & 2.980 & 0.009 \\
\hline $\mathrm{C}$ & 1.822 & 2.615 & 0.697 & 0.495 \\
\hline R-squared & 0.748 & $\begin{array}{l}\text { Adjusted } \quad \text { R- } \\
\text { squared }\end{array}$ & 0.615 & \\
\hline
\end{tabular}

Note : Standard Errors are shown in parenthesis ( ) while t- statistics are shown in brackets [ ] where * shows the probability at $10 \%$ i.e. < o .1, ** shows the probability at $5 \%$ i.e. $<0.05$ and ${ }^{* * *}$ shows the probability at $1 \%$ i.e. $<0$.01

Exchange rate represented as 'dollar' has a positive relationship with sales tax and federal excise duty having coefficient of 1.387 and 0.255 respectively. However it has negative relationship with income tax and customs. The positive relationship with sales tax is due to fact that sales tax is charged on all types of imports with exception of a few items, and major portion of sales tax is derived from petroleum products whose demand is inelastic. So increase in imports increases nominal prices of goods and thus increases sales tax collection. Similarly import of tobacco and beverages are most important source of federal excise at import stage. As demand of these items is less elastic, so federal excise collection increase in relation to increase in nominal price of goods. Decrease in customs and 


\section{Review of Economics and Development Studies, Vol. 7 (1) 2021, 63-76}

income tax is due to fact that higher amount of custom duties are levied on luxury items. As demand for luxury goods is elastic therefore depreciation of rupee increases prices and thus reduces demand and consequently decreases customs duties. Similarly increase in price of goods increases price of final goods and so the demand of them decreases and the producers have to sell them at low profit thus contributing low to income tax. This finding is in consonance to the literature which suggests that price elasticities of demand determine the tax revenue. The results on other variables are also in line with the findings of literature review.

\section{Conclusions and Policy Recommendations}

This paper studies the effect of depreciation of Pak Rupee on tax collection by FBR over the period of 1990-2018 and distinguishing this effect between overall tax collection and types of taxes. ARDL methodology has been adopted and the results were cross checked with FMOLS and ECM and the model is found correct both for long term and short term.

Depreciation of Pak rupee negatively affects overall tax collection both in short run and long run. Its effect is particularly detrimental in case of income tax and customs. In case of income tax it deteriorates tax collection by reducing real income of person and business and in case of customs it reduces demand through price elasticity of demand as imports become more costly. Although depreciation of rupee effects sales tax collection positively as it quickly promotes inflationary trends but as income tax and sales tax are two major taxes in Pakistan with income tax having biggest share, therefore the overall tax collection is negatively affected due to depreciation of Pak rupee.

Agriculture growth has a negative relationship with overall tax collection and its effect is very significant in short run and long run. Industrial growth has a negative relationship with depreciation and tax collection. Service sector growth has negative relationship with depreciation and it negatively affects overall tax collection. Consumption has a positive relationship with tax collection in general and with all taxes in particular and negative relationship with depreciation. Rupee depreciation has a positive relationship with interest rate and tax collection and is significant both in the short term and long term. This relationship is also present with customs and excise. Depreciation of rupee has a positive relation with inflation/CPI. Remittances has a positive and strong relationship with rupee depreciation and tax collection and affects all types of taxes. Import has negative relationship with rupee depreciation and tax collection. Increase in rural population has positive relationship with depreciation of rupee and positive and strong relationship with total tax collection.

Withholding tax regime is the engine of Pakistan's growth but it is regressive in nature and its burden is falling more upon the poor persons of Pakistan and even on those people who are not liable to be taxed. Consumption is very important determinant of tax revenue in Pakistan, but withholding is effecting it through increase in prices of goods and services. The optimization of withholding tax rates with respect to tax collection needs to be done in fiscal policy formulation. Since the industrial growth is not contributing significantly in the growth of tax revenues therefore the government should needs to review its policy of granting generous exemptions to the industrial sector. Although agriculture growth has no positive relation with tax collection but on the contrary as majority of Pakistani population still live-in villages so increase in the income and expenditure of the rural population can have a significant and positive impact on tax collection indirectly through withholding taxes. The government should try to raise living standards of the villages. Since tax collection is highly affected by the remittances and the indigenization process in gulf and decline in oil prices can severely affect this, therefore the government

should take forestalling steps to mitigate this problem. 


\section{Review of Economics and Development Studies, Vol. 7 (1) 2021, 63-76}

Pakistan tax collection is highly susceptible to external shocks and any major local or international events cause's fluctuations in tax collection. This is an inherent flaw of withholding taxes. As government has shifted entirely towards indirect taxes in the form of withholding taxes, there is need to increase its proportion of direct taxes so that in case of any volatility in the domestic or international environment the government programs should not get affected. Depreciation of Pak Rupee is highly integrated and correlated negatively with almost all the major tax determinants of Pakistan. It is one of the most decisive factors which effect the behavior of other variables so it is recommended that the value of dollar should not be allowed to increase.

\section{Reference(s)}

Aghevli, B. B., \& Khan, M. S. (1978). Government deficits and the inflationary process in developing countries. Staff Papers, 25(3), 383-416.

Ahmed, M. A. (2018). Pakistan: With holdinization of the Economic System. A Source of Revenue, Civil Strife or Dutch Disease. Pakistan Development Review, 57(4), 1-43.

Ahmed, Q. M., \& Muhammad, S. D. (2010). Determinant of tax buoyancy: empirical evidence from developing countries. European Journal of Social Sciences, 13(3), 408-418.

Ayodele, O. S., \& Obafemi, F. N. (2003). Fiscal adjustment to currency devaluation in Nigeria: An empirical analysis. Nigerian Journal of Economics and Development Matters,1(1),92-109.

Azhar, B. A. (1996). Tax Pilferage-Causes and Cures. The Pakistan Development Review, 35(4), $657-667$.

Bilquees, F. (2004). Elasticity and Buoyancy of the Tax system in Pakistan. The Pakistan Development Review, 43(1), 73.

Bird, R. M. (1976). Assessing tax performance in developing countries: a critical review of the literature. Finanz Archiv/Public Finance Analysis, (H. 2), 244-265.

Chaudhry, I. S., \& Munir, F. (2010). Determinants of Low Tax Revenue in Pakistan. Pakistan Journal of Social Sciences (PJSS), 30(2).

Cheeseman, N., \& Griffiths, R. (2005).Increasing tax revenue in sub-Saharan Africa: The case of Kenya. OCGG Economy Analysis, (6).

Chelliah, R. J., Baas, H. J., \& Kelly, M. R. (1975). Tax ratios and tax effort in developing countries, 1969-71. Staff papers, 22(1), 187-205.

Egwaikhide, F. O., Chete, L. N., \& Falokun, G. O. (1994). Exchange rate depreciation, budget deficit and inflation: The Nigerian experience. AERC Research Paper, 26.

Gerald Turley (2005). Transition, Taxation and the State. Ashgate Publishing, Ltd.

Gupta, A. S. (2007). Determinants of tax revenue efforts in developing countries. International Monetary Fund Working Paper, 7-184

International Monetary Fund.(1989). Government Finance Statistics Yearbook. Washington, D.C.

Ireland, P. N. (2001). The real balance effect. National Bureau of Economic Research Working Paper No, 8136.

Jayasinghe, M. (2007). Pakistan: A Preliminary Evaluation of the Tax Gap. Georgia State University.

Kemal, M. A. (2007). Fresh assessment of the underground economy and tax evasion in Pakistan: causes, consequences, and linkages with the formal economy. PIDE Working Papers

Khan, M. S., \& Lizondo, J. S.(1987). Devaluation, fiscal deficits, and the real exchange rate. The World Bank Economic Review, 1(2), 357-374.

Krueger, A. O. (1978). Foreign trade regimes and economic development: Liberalization attempts and consequences. Massachusetts: Ballinger Publishing Company

Kumar, M. M. S., \& Ter-Minassian, M. T. (2007). Promoting fiscal discipline. International Monetary Fund. 


\section{Review of Economics and Development Studies, Vol. 7 (1) 2021, 63-76}

Lambertini, L., \& Tavares, J. A. (2005). Exchange Rates and Fiscal Adjustments: Evidence from the OECD and Implications for the EMU. Contributions in Macroeconomics, 5(1).

Leuthold, J. H. (1991). Tax shares in developing economies a panel study. Journal of development Economics, 35(1), 173-185.

Lizondo, J. S., \& Montiel, P. J. (1989). Contradictory devaluation in developing countries: an analytical overview. Staff Papers, 36(1), 182-227.

Loxley, J. (1990). Structural adjustment in Africa: reflections on Ghana and Zambia. Review of African Political Economy, 17(47), 8-27.

Mahdavi, S. (2008). The level and composition of tax revenue in developing countries: Evidence from unbalanced panel data. International Review of Economics \& Finance, 17(4), 607-617.

Malik, M. H., \& us Saqib, N. (1989).Tax incidence by income classes in Pakistan. The Pakistan Development Review, 13-25.

Mujahid, N., \&Zeb, A. (2014.) Impact of Devaluation on GDP of Pakistan. International Journal of Economics and Empirical Research, 2(8), 345-349.

Pasha, H.A. (1995). Political Economy of Tax Reforms: The Pakistan Experience. Pakistan Journal of Applied Economics,11(1-2),129-154

Pazos, F. (1989). Need to Design and Apply a More Effective Anti-Inflationary Plan in Latin America. Journal of Interamerican Studies and World Affairs, 31(1-2), 105-124.

QadirPatoli, A., Zarif, T., \& Syed, N. A. (2012). Impact of inflation on taxes in Pakistan: An empirical study of 2000-2010 period. Journal of Management and Social Sciences, 8(2), 3141.

Refaqat, S. (2008). Social Incidence of Indirect Taxation in Pakistan (1990-2001) (Doctoral dissertation, University of Bath).

Roca, S., \& Priale, R. (1987).Devaluation, Inflationary Expectations and Stabilization in Peru. Journal of Economic Studies, 14(1), 5-33.

Stotsky,J.G.andWoldeMariam,A.(1997).Tax Effort in Sub-Saharan Africa. Working Paper107:International Monetary Fund,Washington,DC

Tait, A. A., Grätz, W. L., \&Eichengreen, B. J. (1979). International comparisons of taxation for selected developing countries, 1972-76. Staff Papers, 26(1), 123-156.

Ter-Minassian, T. (2007). Globalization, Financial Markets, and Fiscal Policy, Prepared by the Fiscal Affairs Department. International Monetary Fund, November, 16.

World Bank.(2018). World development indicators database.

Yiheyis, Z. (2000). Fiscal adjustment to currency devaluation in selected African countries: An empirical analysis. African Development Review, 12(1), 1-23. 